\title{
Cores set to unearth hole picture of evolution
}

Rex Dalton, Boston

Two drilling projects to extract rock cores from formations in Africa and Australia could provide the most comprehensive analysis yet of the early evolution of life on Earth.

The two teams plan to drill nearly two kilometres into sediments that formed between 2 billion and 3 billion years ago. By analysing the resulting cores, they hope to obtain an unrivalled biogeochemical picture of a period of dramatic changes. These included a large increase in the atmospheric concentration of oxygen, which caused sulphur-metabolizing microorganisms to be superseded as the planet's dominant organisms by bacteria that respired aerobically (see Nature 410, 862-864; 2001).

One team, led by Andrew Knoll, a palaeontologist at Harvard University, is expected early next year to win funding from a private foundation for its project in South Africa. The second team, which plans to drill in Western Australia, is led by geochemist Ariel Anbar of the University of Rochester in New York. It is considering applying for support from the US National Science Foundation's programme in biocomplexity, which is seeking project applications in February. There are also talks between the two teams about joining forces in the future.

"Projects like these must be done if we are

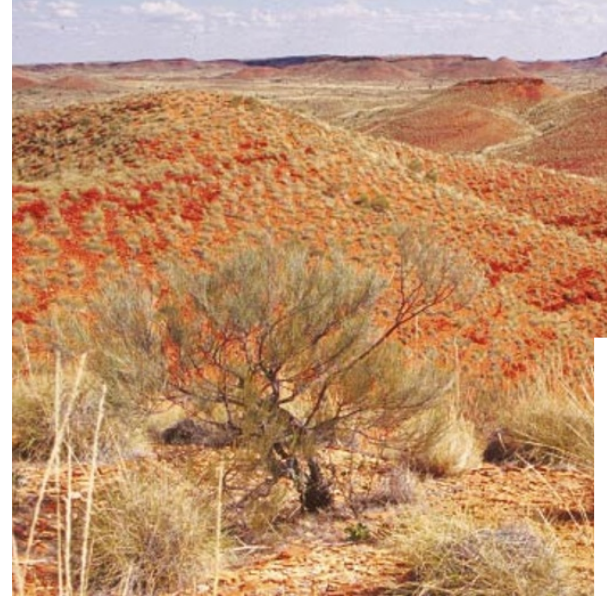

Digging deep: the projects hope for better samples than those that come from mining (right) in areas such as the Pilbara Craton in Australia (above).

to understand the 'deep time' history of this planet," says Roger Buick, an Australian palaeobiogeochemist who recently moved to the University of Washington in Seattle.

Both teams are seeking pristine rock cores - as free as possible of contaminants from regions that offer accessible ancient rock formations. "The shortage of good core samples has become a serious drawback," explains Buick, who is a member of Anbar's

\section{Students left cold by careers advice}

\section{Paul Smaglik, Washington}

US graduate students appreciate the education that their universities provide, but feel they get too little career guidance, according to a new survey. The results, published on the Internet by the National Association of Graduate-Professional Students (NAGPS), confirm the suspicions of many university deans.

Some 32,000 graduate students responded to the survey, which was designed to measure the extent to which universities have adopted reforms proposed recently by bodies such as the National Research Council and the Association of American Universities. Such organizations argue that students should be more broadly prepared for diverse scientific careers.

The survey's data indicate that many graduate students feel that supervisors focus on training students for academic careers, sometimes to the exclusion of other options, says Kimberly Wells, past president of the NAGPS - even though academic opportunities are limited in some disciplines. Some students commented that just mentioning non-academic careers could get them labelled "black sheep", says Wells. Others noted that they were frowned upon for considering a teaching career.

Robert Thach, dean of the graduate school of arts and sciences at Washington University in St Louis, Missouri, says he knew that his graduate school could do a better job in career guidance: "But this poll underscores my impressions dramatically." Lewis Siegel, vice-provost and dean of the graduate school at Duke University in Durham, North Carolina, agrees. "In most scientifically oriented disciplines, they've hit the nail on the head," he says.

But both Thach and Siegel criticize the survey's methodology. The total number of participating students is too low for results to be "statistically compelling", Thach says.

Most controversially, the report attempted to rank individual institutions for graduate student satisfaction — requiring only a minimum of 10 replies from a department. Deans argue that these sample sizes are much too low to give reliable results.

The NAGPS will repeat the survey next year, publishing the results in spring 2003. http://survey.nagps.org

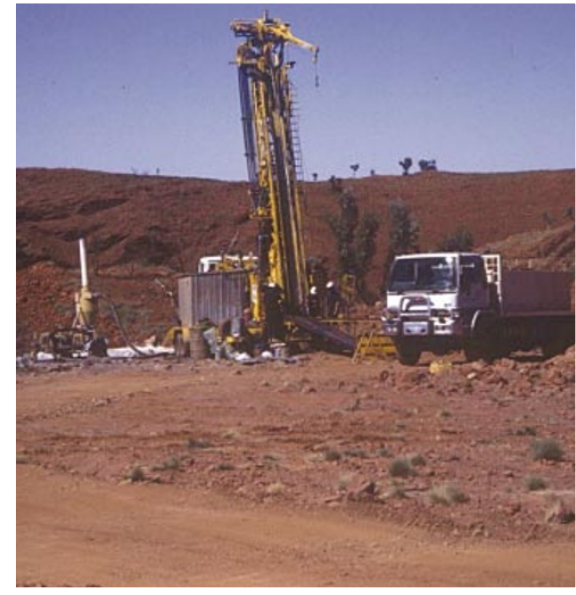

team. Previous studies have been conducted on cores taken during mining operations, which can easily become contaminated.

Knoll's team includes researchers from the Massachusetts Institute of Technology, the California Institute of Technology and Woods Hole Oceanographic Institution in Massachusetts. He declines to discuss funding details, although the initial phases are expected to cost several hundred thousand dollars. Scientists familiar with the project say the team has received strong assurances of support from the Agouron Foundation of Pasadena, California.

If this funding is secured, drilling could start before the end of next year in part of the Transvaal region of South Africa. Cores taken here could capture the geological formations of sediments ranging from tidal flats to the ocean floor laid down between 2.2 billion and 2.6 billion years ago.

Anbar's team of some 70 Earth scientists, meanwhile, is eyeing sites — such as the Warrawoona formation in Western Australia - where rocks on the surface have produced some of the earliest evidence for microbial life. Drilling here could yield cores between 2 billion and 4 billion years old. Again, Anbar says it is too early to discuss a precise pricetag for the project. Drilling could start within a year of the project winning funding.

The two projects could also provide crucial baseline data for future investigations into the biogeochemical signatures of life on other planets. "For a fraction of the cost of a space machine, we could do a nice job on samples from early Earth," says Anbar. 